\title{
Müzede Aydınlatmanın Kullanıcı ve Eserler Açısından Değerlendirilmesi
}

\author{
Uğur Özcan ${ }^{1 *}$, Hümeyra Çağlar ${ }^{2}$ \\ ${ }^{1}$ Fatih Sultan Mehmet Vakıf Üniversitesi, Mimarlık ve Tasarım Fakültesi, Mimarlık Bölümü, İstanbul, Türkiye (ORCID: 0000-0003-0002-4478) \\ ${ }^{2}$ Fatih Sultan Mehmet Vakıf Üniversitesi, Lisansüstü Eğitim Enstitüsü, Mimarlık Anabilim Dalı, İstanbul, Türkiye (ORCID: 0000-0003-2602-9189)
}

(İlk Geliş Tarihi 14 Şubat 2020 ve Kabul Tarihi 18 Mart 2020)

(DOI: 10.31590 /ejosat.703797)

\begin{abstract}
ATIF/REFERENCE: Özcan, U. \& Çağlar, H. (2020). Müzede Aydınlatmanın Kullanıcı ve Eserler Açısından Değerlendirilmesi. Avrupa Bilim ve Teknoloji Dergisi, (18), 645-655.
\end{abstract}

Öz

Müzeler, bir toplumun bilim, sanat, kültür ve tarih alanlarında değerli görülen eserlerinin sergilendiği, saklandığı ve korunduğu yapılardır. İlk müze 16. yüzyılda, ilk resmi müze ise 18. yüzyılda oluşturulmuştur. Bu dönemlerde kurulan müzelerde amaç, sadece nesnelerin bol güneş 1şığı altında sergilenmesidir. 19. yüzyılda sergileme işlevine ek olarak insanların sosyalleştiği, eğitimsel ve kültürel etkinlikler ilave edilmiştir. Müzeler bulundukları şehirlerde birer röper noktası haline gelseler de, ana işlevleri olan sergileme devam ettirilmektedir. 20. yüzyıldan sonra ise artık koleksiyon nesnelerinin korunması gündeme gelmiştir ve doğal 1şık kontrolüyle birlikte yapay ışık ve yansıtıcılar kullanılmaya başlanmıştır. Müzelerde sergilemeden sonra ikincil işlev, insanlığın kültürel ve tarihi değerleri olan nesnelerin toplanması ve korunmasıdır. Ancak sergileme esnasında fiziksel ve çevresel faktörler nedeniyle sergilenen nesneler zarar görmekte ve bozulmalara uğramaktadır. Sergilenen nesneler, tüm insanlığın ortak değeri ve kültür mirası haline dönüşmüştür. Bu nedenle büyük tahribatların geri dönüşü zor, hatta imkânsız olabilmektedir.

Sergileme, birincil işlev olduğundan, sergilenen nesnelerin doğru algılanabilmesi çok önemlidir. Eserlerin algılanabilmesi fiziksel temas sağlanarak gerçekleştirilemediğinden görsel algılama ve aydınlatma önemlidir. Maksimum algı için doğru aydınlatma sisteminin, 1şık miktarının ve 1şı̆̆ın renginin seçimine dikkat edilmelidir. Aydınlatma sistemi hem kullanıcı gereksinimlerinin karşılanması, hem de nesnelerin 1şıktan kaynaklanacak tahribatlara uğramaması iki önemli faktördür. Kullanılan aydınlatma tasarımı ziyaretçiler için görsel konforu sağlamalı, nesnelerin doğru algılanmasını, tanımlanmasını ve tasarımın göze hoş gelmesini sağlayacak düzeyde olmalıdır. Ayrıca 1şıklandırma ile mekânın davetkar olması ve ilgi çekmesi hedeflenmelidir. Sergi objelerinin vurgulu aydınlatıldığı özel durumlarda, kullanıcıların yön ve mesafe bulabilmesi sağlanmalı; olası çarpma, düşme gibi durumlarda hem ziyaretçinin hem de materyallerin zarar görmesi önlenmelidir.

Koleksiyon nesnelerinin aydınlatılması, sergileme amacı ve nesnelerin içeriğindeki malzemelere göre farklılık göstermektedir. Bu nesneler uzun yıllardır ışık gibi çevresel etkilerle karşı karşıya kaldığından, zamanla hassasiyetleri artmaktadır. Işı̆̆ın nesnelerde oluşturabileceği tahribatlar, nesnenin kimyasal özelliklerine göre farklılık göstermektedir. Genelde bu bozulmalar; renk değişimi/solması, yapının zayıflaması ve kırılganlaşması, ışık kaynağından yayılan ısıya bağlı yüzeyde genleşme ve çatlaklar olarak meydana gelmektedir.

$\mathrm{Bu}$ çalışma kapsamında, kültürel mirasların korunup sergilendiği müzelerde, 1şık faktörünün ve etkilerinin, aynı zamanda 1şı̆̆ın olumsuz etkilerine karşı alınabilecek tedbirlerin incelenmesi amaçlanmıştır.

Anahtar Kelimeler: Müze, Sergi, Işı, Doğal Aydınlatma, Yapay Aydınlatma.

\section{Evaluation Of Lighting In The Museum In Terms Of Users And Artifacts}

\begin{abstract}
Museums are structures in which works of a society deemed valuable in the fields of science, art, culture and history are exhibited, stored and preserved. First museum 16. in the century, the first official museum is 18. it was created in the century. The purpose in museums established during these periods is only to display objects in abundant sunlight. 19. in addition to the exhibiting function in
\end{abstract}

* Sorumlu Yazar: Fatih Sultan Mehmet Vakıf Üniversitesi, Mimarlık ve Tasarım Fakültesi, Mimarlık Bölümü, İstanbul, Türkiye (ORCID: 0000-0003-0002-4478) uozcan@fssm.edu.tr 
the century, people socialized, educational and cultural activities were added. Although museums have become points of interest in the cities in which they are located, their main function, the exhibition, continues. 20. after the century, however, the preservation of collection objects was brought to the agenda and artificial light and reflectors began to be used along with natural light control. The secondary function after display in museums is the collection and preservation of objects with cultural and historical values of humanity. However, the objects exhibited during the exhibition are damaged and deteriorated due to physical and environmental factors. The objects on display have been transformed into the common value and cultural heritage of all humanity. Therefore, it can be difficult or even impossible to recover from major destruction.

Because exhibiting is the primary function, it is very important that objects exhibited can be perceived correctly. Visual perception and lighting are important because the perception of the works cannot be realized by providing physical contact. Attention should be paid to the selection of the correct lighting system, the amount of light and the color of the light for maximum perception. The lighting system meets the needs of the user, and the objects do not suffer from the destruction caused by light are two important factors. The lighting design used should provide visual comfort for the visitors, to ensure that the objects are correctly perceived, identified and the design is pleasing to the eye. It should also be aimed to make the place inviting and interesting with lighting. In special cases where exhibition objects are highlighted, users should be able to find direction and distance; in case of possible impact or fall, damage to both the visitor and the materials should be prevented.

The illumination of the objects of the collection differs according to the purpose of the exhibition and the materials in the contents of the objects. Because these objects have faced environmental impacts such as light for many years, their sensitivity increases over time. The effects that light can cause on objects vary according to the chemical properties of the object. In general, these distortions occur as discoloration/fading, weakening and brittle of the structure, expansion and cracks on the surface due to heat emitted from the light source.

Within the scope of this study, it is aimed to examine the light factor and its effects, as well as the measures that can be taken against the negative effects of light in museums where cultural heritage are protected and exhibited.

Keywords: Museum, Exhibition, Light, Natural Lighting, Artificial Lighting.

\section{Giriş}

Müzeler genellikle kültür, sanat, bilim, tarih alanlarının ve bu alanlara etkisi olmuş materyallerin saklandığı, korunduğu, bakımının yapıldığı ve insanlara süreli veya sürekli olarak sergilendiği yapılardır.

"Müze" kavramı ilk olarak 16. yüzyılda Medici ailesinin kendisine ait eserleri sergilemeye başlamasıyla ortaya çıkmıştır. Daha sonra 1750 yılında ilk resmi müze olan Lüksemburg Müzesi, kraliyet ailesine ait eşyaları halka sergilemek amacıyla hizmet vermeye başlamıştır. İlk üniversite müzesi olma özelliği taşıyan ve 1677 yılında Oxford Üniversitesi’ne bağışlanmış Ashmolean Müzesi, ilk kamusal müze olma özelliğini de taşımaktadır (Erdemir, 2014).

İlk müzeler kurulduğunda amaç, sadece sanat eserlerinin sergilenmesidir. Bu nedenle genelde dikdörtgen planlı, tepe 1şıklığı olan, içe kapalı kutucuklar şeklinde yapılar olarak tasarlanmışlardır. Ancak zamanla sanat eseri sergileme fonksiyonuna ek olarak eğitimsel ve sosyal boyutlar da eklenmiş, müze binaları tasarımı da deneyimsel bir boyut kazanmıştır (Soygeniş, 1992). Müzeciliğin bu ilk yıllarında eserleri bol günışığı altında sergilemek hedeflenmiştir. 18. ve 19. yüzyıl mimarisinde ise 1 şığı kontrol altına almak amacıyla doğal ışığı mekân içine alan pencere sayısı azaltılmış, yüksek pencereler, tepe 1şıklıkları ve yansıtıcılar yapılara dâhil edilmiştir.

20. Yüzyılın ortalarında sergilenen objenin zararlı ışınlardan korunması önem kazanmış, bu bağlamda bazı değişiklikler yapılmıştır. Bunlar, mekân içindeki günışığının kurgulanmış bir sistemle kontrolü ve sadece yapay aydınlatma kullanımını yaygınlaştırmaktır. Daha sonraki süreçte, gelişen teknoloji ve zamanla tükenen kaynaklar sebebiyle enerji tasarrufu gereksinimleri göz önünde bulundurularak günışığının aktif bir şekilde kullanımı öngörülmüştür. Böylece gerekli aydınlık düzeylerinin sağlanması, görsel konfor ve eserlerin korunumu mümkün olmuştur (Soygeniş, 1992).

\section{Müzeciliğin Gelişimi ve Modern Müze Anlayışı}

19. yüzyıldan sonra müze mimarisindeki klasik dikdörtgen form terk edilmiş, farklı geometrik formlar kullanılarak anıtsal yapılar tasarlanmıştır. 1970'li yıllarda müzeler kentsel ikonlar haline dönüşerek insanların ilgisini çeken ve davet eden birer toplanma merkezlerine dönüşmüştür. Artık sanat eseri sergilemenin yanı sıra müze yapılarının de birer sanat eseri niteliğinde değerlendirilme durumu ortaya çıkmıştır. Bu yıllardan itibaren müzeler sergileme görevinin yanı sıra insanların eğitim ve kültür aktivitelerini gerçekleştirdikleri, sosyalleştikleri, çalışma ve araştırma işlevlerini gerçekleştirebilecekleri komplekslere dönüşmüştür. Bu işlevleri karşılayabilmek için de sinema, video odaları, depolar, kafeteryalar, konferans ve eğitim salonları gibi daha geniş hacimlere ihtiyaç duyulmuştur.

Günümüz modern müzeciliğinde müzeler, çağın modern iletişim araçlarına yönelmektedir. Koleksiyonları, özel sergileri ve tanıtımlarını modern iletişim araçlarıyla izleyicilere sunmaktadırlar. Bu anlamda modern müze, ziyaretçi bekleyen ya da çeken değil sahip oldukları modern iletişim teknikleri ile müzeyi insanların ayağına götüren 'mobil müzecilik' anlayışına yönelmektedir (Okan, 2018). Modern müze anlayışında sürekli ve değişken alanlar önem kazanmıştır. Giriş, koridorlar ve sirkülasyon alanları; yatay ve düşey bağlantılar, rampalar, merdivenler sanat eserlerinin sergilenme durumuyla birlikte, binanın esas tasarım girdisi olarak düşünülmektedir (Erdemir, 2014). 
Müzelerin öncelikli hedefi olan sergilemenin yanında ikincil işlevleri toplama ve korumadır. Tüm bu görevleri yerine getirebilmek için iyi tasarlanmış bir mimari oluşuma ihtiyaç duyulmaktadır. Gerekli sergileme alanları, giriş ve bekleme salonları, depolar, sirkülasyon alanları gerekli teknik donanıma sahip değilse fonksiyonlar yerine getirilememektedir.

Bu teknik donanımların başlıcaları şunlardır; Havalandırma, Depolama, Güvenlik Sistemleri, Restorasyon, Koleksiyon, Arşiv, Envanter, Aydınlatma (Okan, 2018).

Müzeler için en önemli fonksiyon olan nesne ve sanat eseri sergilemesi, doğrudan aydınlatma ile alakalıdır. Işığın doğru açıyla ve doğru miktarda aydınlatması, sergilenen eserin algılanmasında büyük rol oynamaktadır.

\section{Işık ve Aydınlatma}

\subsection{Işık Kavramı}

Işık, dalga şeklinde yayılan ve parçacık etkili, göze tesir eden özel bir enerji şeklinde tanımlanır. Kasap'a göre aydınlatma, çevrenin ve nesnelerin, belirli bir amaca uygun olarak teknik altyapının yanı sıra sanatsal ve imgesel boyutunun da önceden kurgulanarak 1şık bütünselliğinin yaratıcılıkla harmanlandı̆̆ı bir görsel anlatım aracıdır (Kasap, 2016). Ayrıca 1şık; görmenin, algılamanın ve ait hissetmenin de temel araçlarındandır.

Bir mekânın şekli, yüzeyleri, iç mekânının estetik görünümü, dokuları, ölçeği, sınırları, rengi ve sunmak istediği duygusal his yapının ışık ile olan ilişkisiyle ortaya çıkar. Mekâna karakter veren ışık, mimarlık ve aydınlatma arasındaki ilişkinin temel öğesini oluşturur (Yöndem, 2019).

\subsection{Aydınlatma Terimleri}

\subsubsection{Işık Akısı}

Işık kaynağından çıkan ve her yöne dağılan, normal gözün gündüz görmesine ait spektral duyarlılık eğrisine göre değerlendirilen toplam 1şık miktarına denir ve lümen (lm) ile ölçülür. Aydınlatma aygıtının gücü arttıkça akı da artar (URL-1).

\subsubsection{Işı Şiddeti}

Noktasal 1şık kaynakları için tanımlanır ve doğrultuya bağlı bir büyüklüktür. Iş̧k kaynağının belirli bir yönde akan ve candela (cd) birimine sahip olan ışık akısı miktarıdır (URL-1). İdeal noktasal bir lamba, ışık akısını her yöne eşit aralıklı yaymaktadır. Bununla birlikte, pratikte ışık kaynağının verdiği ışık akısı sabit olduğu halde, çeşitli doğrultulardaki ışık şiddeti farklı olabilir. Bu, kısmen ışık kaynağının tasarımından veya ışığın kasıtlı olarak yönlendirilmesinden kaynaklanmaktadır (Ganslandt ve Hofmann, 1992).

\subsubsection{Aydınlık Düzeyi}

Birim alana düşen ışık akısı miktarıdır. Işık akısı kaynaktan çıkan tüm ışık miktarını belirtirken, aydınlık düzeyi yüzeyin ne kadar ışık aldığını gösterir. Birimi lükstür (lx) ve ışık akısının yüzey alanına oranı ile bulunur $\left(1 \mathrm{~m} / \mathrm{m}^{2}\right)$.

Müzelerde aydınlık düzeyinin dağı̆lımı, aydınlatma amacına bağlı olarak bölgesel aydınlatma ve genel aydınlatma olmak üzere iki gruba ayrılabilir. Düzlemin her noktasındaki aydınlık düzeyi üzerinde belirgin bir değişiklik yoksa, yani değerler birbirine çok yakınsa düzgün yayılmış genel aydınlatma (Emin/Eort $>0.8)$; aydınlatılan alanın her noktasındaki aydınlık düzeyinin eşit olmadığı durumlarda ise değişken yayılmış genel aydınlatma elde edilmiş olur (Bayer, 2007).

\subsubsection{Parıltı}

Prof. Şazi Sirel, Aydınlatma Sözlüğü’nde parıltıyı bir yüzeyin az ya da çok ışık yayımlar görünmesine bağlı görsel duyulanma verisi şeklinde tanımlamışırı (Sirel, 2012).

Işık kaynaklarından gelen veya yüzeyin yansıttığı ışık miktarı olarak tanımlamak mümkündür. Nesnenin görünebilirliği, nesnenin görünen yüzeyinin parıltısına bağlıdır. Parıltı ise yüzeyi aydınlatan ışık miktarına, yüzeyin görüntülenme açısına ve yüzeyin yansıtma özelliklerine bağlıdır (Yöndem, 2019).

Birimi nesneler için nit, 1ş̧1k kaynakları için stilb'dir; 1şık şiddetinin yüzey alanına oranı ile bulunur $\left(\mathrm{cd} / \mathrm{m}^{2}\right)$.

\subsubsection{Renk Sicaklı̆̆}

Renk sıcaklığı, ışı̆̆ın sıcak veya soğuk görünmesini açıklayan aydınlatma tekniğinin bir terimidir. Birimi Kelvin (K)'dir. Yapılan araştırmalardan elde edilen veriler, renk sıcaklığı arttıkça göreceli hasar potansiyelinin arttığı yönündedir. Bu etki, müzede düşük renk sıcaklıklı ışık kaynaklarının genel kullanımının koruma için tercih edilmesini sağlamıştır. Ancak ışık renk sıcaklı̆ğına ilişkin kararlar, sergilenen nesnelerin görünür özellikleri dikkate alınarak verilmelidir. Müzelerde önerilen renk sıcaklığı değerleri 2900- $4200 \mathrm{~K}$ aralığındadır (Yöndem, 2019).

\subsubsection{Renksel Geriverim Índeksi}

Işık kaynaklarının aydınlattıkları cisimlerin renklerini ayırt ettirebilme özelliklerine, ı̧̧ık kaynağından görülen gerçek renk tonuna verilen addır. Renksel geriverim ölçeği 0'dan 100'e kadardır. Doğal ışık, bu özellikte en üst seviyededir ve değeri 100'dür (Hunt, 2009). 
Renksel geriverim indeksi, izleyicinin renkleri doğru görme becerisi açısından 1şık kalitesini ölçer. Sergilenen nesnelerin olduğu renklerde algılanabilmesi ve ışı̆̆ın renk değişimlerine neden olmaması müzelerde önemli bir kriterdir. Müzeler tarafindan belirlenen sabit bir renksel geriverim indeksi yoktur. Fakat genel olarak müzelerde kullanılacak lambaların seçiminde renksel geriverim indeksinin (CRI) 85 veya üzerinde değer alması önerilir. Müze aydınlatma tasarımcılarının, yüksek renksel geriverim indeksine sahip sürekli spektrumlu ışık kaynaklarını seçmeleri ve serginin genel görünümüne ve ayarlarına uyacak ışık renk sıcaklıklarını belirlemeleri yaygın bir uygulamadır (Yöndem, 2019).

\section{Müzelerde Aydınlatma}

Işık, bina tasarımlarının vazgeçilmez unsurlarından biridir. Müzelerde aydınlatma tasarımları ise hem mekânın hem de serginin amacına ulaşabilmesi için ön plana çıkmaktadır. Genel olarak müzeciliğin ilk yıllarında amaç eserleri bol ışık altında sergilemek olmuştur. Daha sonraları müzeler bilimsel, tarihsel ve sanatsal eserlerin sergilendiği ve korunduğu kuruluşlara dönüşmüştür. Bu eserler insanlığın ortak değerleri olarak ele alındığından herhangi bir tahribata uğradığında geri dönüşü olmayacağ düşünülerek, gün 1şı̆̆ına oranla daha az zararlı yapay aydınlatmalar devreye girmiş ve koruma kavramıyla birlikte ele alınmıştır (Yöndem ve Akyol,2017).

Günümüzde galeri ve müze aydınlatmasında dört kavram üzerinde durulmaktadır:

1- Bilinçli kullanılmış bir aydınlatma düzeni ile sergilenen nesnelerin görünmesini engelleyen kamaşmanın yok edilmesi, nesnelerin net ve doğru bir şekilde algılanmasının sağlanarak nitelikli bir izleme imkanının tanınması

2- Sergilenen nesnelerin zararlı ışınımlardan korunması

3- Gün ışığını destekleyici yapay aydınlatma düzeninin sağlanması

4- Sergileme yöntemlerinin gelişmesine bağlı olarak nesnelerin biçimsel, gereçsel,

renksel, vb. özelliklerinin ortaya çıkarılması (Kurtay ve diğ.,2003).

\subsection{Aydınlatma Tasarımında Kullanıcı Gereksinimleri}

Müze sergilerinde mekân-yapıt ilişsisi görsel algılama bağlamında oluşur ve gelişir. Sergi alanı, yapının kimliğini aktarıp, onu ziyaretçiye gerekli algılama verileri doğrultusunda, gerekli konfor değerleriyle sunarken, izleyici ile eserin etkileşimini kurmak durumundadır. Müze, koleksiyonunun tanımlanması ve tanınması yolunda düzenlediği sergilemede bir algılama çevresi hazırlamaktadır (Kurtay ve diğ.,2003). Müzede insanların eserlere fiziksel temasta bulunmaları olanaksızdır. Bu nedenle algılama büyük oranda gözle gerçekleşmektedir. Aydınlatmanın ve ışığın etkisi bu durumda oldukça fazladır. Aydınlatma tasarımında görsel konfor, görsel performans ve güvenlik hedeflenmelidir.

Sergi mekanlarının aydınlatmasında müze hem göze hoş gelmeli, hem davetkar olmalı, bunun yanında da sergilenecek elemanlarla uyum içinde olmalıdır. İlk aşamada alınması gereken kararlar gün ışığııın kullanılıp kullanılmayacağı, miktarı, yapay ışığın gün ışığıyla birlikte ve karanlık ortamda nasıl kullanılacağıdır.

Galerinin mimari karakteri, sergilerin nasıl sunulacağı ve aydınlatılacağına bağlı olarak binanın aydınlatılması, sergi ile galeri arasında yeterli bir kontrast oluşturacak şekilde dolaylı veya gizlenmiş aydınlatma düzenekleri içerebilir. Sergilenecek olan nesnelerin, görüş alanı içinde en parlak bölümleri oluşturması amaçlanır. Duvarları, tavanı ve binanın diğer yüzeylerini aydınlatmak için kullanılan gizlenmiş aydınlatma düzeneği, görünürde çalışan armatürler olmadan mekana ışı̆̆ın girmesinin bir yöntemidir. Bu aydınlatma şekli, mimari öğelerin veya yüzeylerin önem kazanması için uygundur ve sergilenecek objelerin aydınlatılması için zemin oluşturur (Kazanasmaz,2003).

Bir nesnenin algılanabilmesi için ebatları ve ışık miktarının eşik değerlerinin üzerinde olması gerekmektedir. Obje; uzunluk, renk, şekil, hareket gibi özellikleriyle içinde bulunduğu ortamda ayırt edilebilmelidir. Şekil ve desen algısında en önemli faktör aydınlık miktarıdır. Derinlik algısında malzeme, yüzeydeki girinti ve çıkıntılar, aydınlık düzeyi ve renk etkilidir. Aydınlatma sistemi, nesnenin öne çıkması istenen özelliğine göre belirlenmelidir.

Sergi aydınlatmasının amacı, sergilenen nesneler üzerinde inceleme yapabilmek olduğu kadar göze hoş gelmesini de sağlamaktır. Bazı sergilerde nesnelerin ince detaylarına kadar gözükmesi ve incelenmesi istenirken, bazılarında nesne bir bütün olarak ele alınmaktadır (Kazanasmaz, 2003).

Işığa çok duyarlı nesnelerin sergilendiği durumlarda, belirlenen aydınlık düzeyinin en alt sınırı ile sadece objelerin vurgulu aydınlatılması sağlanmaktadır. Ancak bu durumlarda ziyaretçilerin nesne ve mekân algısı, yön bulabilmesi de göz ardı edilmemelidir. Böyle durumlarda genel aydınlatma kullanılmadığından insanların hareket alanının belirgin olmaması; çarpma, düşme ve yön bulamama gibi konfor problemlerinin ortaya çıkmasına sebep olmaktadır (Erdemir, 2014). Çarpma gibi durumlarda ziyaretçilerle birlikte sergilenen materyaller de zarar görmektedir. Bu problemler aynı şekilde aşırı 1şık durumunda da söz konusu olacağından görme eyleminin yerine getirilebileceği aralıklarda ışık miktarı kullanılmalıdır.

Müze olarak kullanılan ve kendileri başı başına müzenin bir parçası olarak sergilenen tarihi yapılarda nitelik ve nicelik yönünden ciddi sorunlar yaşanmaktadır. Yapının hem korunması, sergilenen objelere kabuk oluşturması, hem de kendini ve içinde barındırdığı eserleri nitelikli biçimde algılatıp, sergilemesi gerekmektedir. Tarihi yapı bir taraftan korunurken, diğer taraftan kendini sergilemeli ve sergilenen eserler kadar yapı da net bir şekilde algılanmalıdır. Tarihi bir yapıda aydınlatma söz konusu olduğunda, mevcut donanım göz önünde bulundurularak, öneri çözümlerle yapıya minimum zarar verilmesi hedeflenmelidir (Kurtay ve diğ.,2003) 


\subsection{Aydınlatma Tasarımında Sergi Nesnesinin Durumu}

Müzelerde sergilenen objelerin, sergileme amaçlarına ve çeşitlerine göre aydınlatma tasarımları ve ihtiyaçları da farklılık göstermektedir. Bazı objelerde direkt ışığa maruz kalmak zararlı olacağından ışık sınırlandırılmalıdır. Kaynak olarak mümkün olduğunca gün ışığı tercih edilmesine rağmen, sanat eserine vereceği zarar, mevsimsel ve gün içindeki kontrolünün zorluğu sebebiyle günümüz müze ve galerilerinde genellikle yapay ışıklandırmalar tercih edilmektedir.

\subsubsection{Sergi Nesnelerinde Işı̆̆a Bağlı Bozulmalar}

Sergi nesneleri organik, inorganik veya kompozit olarak sınıflandırılabilir. Bu kimyasal sınıflandırmaya göre ışığın malzemeler üzerindeki etkisi değişkenlik göstermektedir. Aydınlatmadan kaynaklanan hasarlar; malzemelerin bozulması veya zayıflaması, inorganik malzemeler ve bağlayıcıların oksidasyonu, nesnedeki yüzey sıcaklığı değiş̧imine bağlı renk değişikliği gibi farklı şekillerde görülebilir.

Ahşap, bulunması ve üretilmesi diğer malzemelere oranla daha kolay olduğundan kullanılan en eski malzemelerdendir. Bu nedenle müze koleksiyonlarında birçok örneğine rastlanmaktadır. Işık; ahşap malzeme içindeki lignin pigmenti ile etkileşime girerek rengin ağarmasına sebep olmaktadır. Zararlı ışınların başında gelen UV ise ahşap yüzeyinde kırılma, pürüzleşme ve çatlaklara yol açmaktadır. Boyalı ahşap yüzeyler ışığa karşı daha dayanıklıdır. Boya, ahşabın dış yüzeyi ile çevresel faktörler arasında bir geçiş alanı oluşturarak reaksiyonlara ahşaptan önce cevap vermektedir.

Kâğıttan yapılmış nesneler, yüksek ışık seviyelerine maruz kaldığında yapısındaki liflerin gevşemesinden dolayı renk değişikliği görülmektedir. Aynı zamanda akkor ampuller gibi ışıkla birlikte 1sı da yayan ışık kaynaklarında, sıcaklık değişimine bağlı olarak kâğıt yüzeyinde kuruma gerçekleşir ve malzeme daha kırılgan bir hal alır.

Tekstil ürünleri; lifler, boyalar ve bitim işlemlerinin sonucunda elde edilen kompozit malzemelerdir. Genellikle organik malzemelerden oluştuğundan sıcaklık, nem, 1şık ve fiziksel etkenlerin neden olacağı bozulmalara duyarlıdır. Doğal veya yapay işık fark etmeden yüksek aydınlatmaya maruz kalmak, içerdiği boyanın renk değiştirmesine, liflerin sağlamlığını kaybetmesine neden olur. Ayrıca tekstil nesnelerde ışık miktarı kadar maruz kalma süresi de bozulma oranını belirler.

Kauçuk ve plastik gibi inorganik materyallerde bozulmanın hangi oranda gerçekleşeceği öngörülemez. Bozulma; kimyasal bileşiminde, fiziksel özelliklerinde veya formunda değişiklikler şeklinde görülebilir.

Metal nesneler de ahşap gibi müze koleksiyonlarında geniş bir yere sahiptir. Metal nesnenin bozulmasında nem, sıcaklık ve yanlış bakım gibi faktörler etkili olmaktadır. Metaller, ışığa karşı dayanıklı olsa da uygulanan bakımlar nedeniyle dikkat edilmesi gereken bazı durumlar vardır. Örneğin; metal obje üzerinde bir kaplama varsa UV ışınları kaplamanın koruyucu özelliklerini kaybetmesine sebep olmaktadır. Zamanla yüzeyde kararmalar meydana gelmektedir. Bu nedenle sürekli bakım gerekmektedir.

Seramik, cam gibi nesnelerin en belirgin özelliği gevrek ve kırılgan olmalarıdır. Bozulma etkenlerinin başında fiziksel gü̧̧ gelmektedir. Kızı̈ötesi (IR) ışınlar bu nesnelerde sıcaklık ve nem değişimine bağlı yüzey genişlemesi veya daralmasına neden olmaktadır. Ayrıca cam yüzeylerde matlaşma ve renk değişimi görülmektedir. Camların güneş ışığı veya 1sı yayan spotlar altında sergilenmesi, kırılma veya çatlaklara yol açmaktadır.

Beton, cam, taş, metal gibi materyallerden yapılmış bazı koleksiyon nesneleri dış mekanda sergilenmektedir. Her ne kadar dayanıklı malzemeden üretildikleri düşünülse de süreç içinde bozulmaları kaçınılmazdır. Fiziksel hasarlar ve iklimsel koşullarla birlikte ışık, bu nesneler üzerinde korozyon, renk değişikliği ve kuruyarak kırılgan hale gelme gibi değişimlere neden olmaktadır.

\subsubsection{Sergi Nesnesinin Korunmast}

Tüm ışık kaynakları ultraviyole yaydıklarından eserler üzerinde belli tahribatlara yol açmaktadırlar. Bu tahribatların minimum seviyeye indirilmesi gerekmektedir. En zararlı ışık güneştir, floresan lambasının ışığı daha az zararlıdır. Bir eser üzerine zayıf ışık verilse bile bu ışık uzun süre tutulursa esere zarar vermektedir. Ayrıca ışığın verdiği tahribatları telafi etmek çok zordur. Solgun renkler ve ışık yüzünden kırılganlaşan eserler orijinal durumlarına gelemezler. Mutlaka filtre kullanılmalıdır. Iş̧ı eserlere direkt gelmemeli, yansıtılmış ışık kullanılmalıdır (Okan, 2018).

Kullanılan aydınlatma düzeneğinin çeşidi kadar lambaların çeşidi de önemlidir. Sergideki objelerin renklerini en iyi ve doğru şekilde göstermek için renksel geriverim endeksi 85 (CRI) veya daha yüksek olan lambalar tercih edilmelidir. Ayrıca, objelerin ışıktan yayılan UV veya IR dalgalarından zarar görmemesi için önlemler alınmalı ya da uygun lambalar seçilmelidir (Kazanasmaz, 2003). Işık, dalga uzunluğuna göre üç kategoriye ayrılan devamlı bir enerji spektrumudur. Bu kategoriler morötesi ışınlar (UV), kızılötesi 1şınlar (IR) ve görülebilir ışıktır. Morötesi ışın, radyasyonun kısa ve en çok enerji barındıran formudur. Kızı̈ötesi ışın (IR), 1şık spektrumunun sonunda yer almaktadır. Görülebilir ışık ise spektrumda mor ötesi ve kızıl ötesi ışınların arasındadır. UV'den kaynaklanan yüksek enerji, organik eserlerde belirgin bir değişime neden olmaktadır. Uzun dalga boyların kısa dalga boylarından daha az zararlı olmasına karşın, emilen enerji eserin yüzeyini ısıtacağı ve kimyasal bozulmayı hızlandıracağı, aynı zamanda bağıl nemde instabiliteye neden olacağı için bu 1şınlar da eserlerde bozulmaya neden olmaktadır. Doğrudan güneş 1şığı 100.000 lüks'e kadar bir değer iken, dolaylı güneş ışığı 10.000 lüks, parlak spot lambalar ise 2.000 lüks değerinde ışık vermektedir (Doğruer, 2019).

Bir çözüm önerisi olarak da ışık alma, yani nesnelerin aydınlatıldığı süre azaltılabilir. Belli bir ışık seviyesine maruz kalan sergi nesnesinin, en azından ziyaretçi olmadığı zaman zarfında ışık alması önlenerek zarar oranı azaltılmaya çalışılmaktadır (Akgün, 2018). 


\section{5. Örnek Müzelerde Aydınlatma Sistemlerinin İncelenmesi}

\section{1. İstanbul Deniz Müzesi}

Bina, tarihi bir koleksiyon için tasarlanmış; geleneksel ile çağdaş müzeciliği buluşturmuştur. Yaya ve araç trafiğinin yoğun olduğu Beşiktaş ilçesinde, bir sakinleştirme noktası olmayı hedeflemiştir. Çevrede röper noktası olarak kabul edilebilecek Beşiktaş Meydanı, İskele Caddesi, Dolmabahçe Caddesi ve İstanbul Boğazı ile görsel bir bağ oluşturması amaçlanmıştır (Yarımay, 2018).

Tescilli bir yapı olan Deniz Müzesi ve ona ek olarak yapılan Kayıkhane binasından oluşmaktadır. Sergileme alanlarının yanı sıra; kütüphane, çocuk eğitim salonu, konferans salonu, kafeterya ve satış birimleri gibi alanların varlığı, müzeye sergi ziyaretçileri dışında insanları da çekmektedir (Sapchi, 2016). Ayrıca müzeye gelir getirmesi amacıyla dönemlik olarak kiralanan geçici sergi salonları, konferans salonu ve fuayeler ile farklı etkinlikleri de bünyesinde barındırmaktadır.

Müze, açık hava sergisi olarak kullanılan avlu etrafında kurgulanmıştır. Giriş, cadde kotundan birinci kattan, binanın denizle bağlantısı zemin katta yarı açık bir alanla sağlanmıştır.

Müzenin giriş holü eski ve yani binaların bağlandığı düğüm noktası rolündedir. Tarihi bina ile Kayıkhane bölümü bir köprüyle bağlanmıştır. Oluşturulan sergi rotasında eski ve yeni binalar bütünleşmektedir. Büyük kayıkların sergilendiği zemin katta, geniş açıklık sistemleri ile kesintisiz görüş alanı sağlanmıştır. Daha küçük kayıkların bulunduğu asma kat ise galerilerle zemin katı görmektedir. Binanın plan ve sergileme şeması, mevcut koleksiyona uyum sağlayacak şekilde düzenlenmiştir. Ayrıca sergi salonları arasındaki rampa ve köprüler, engelli ziyaretçiler için de sirkülasyonu kolaylaştırmaktadır (Yarımay, 2018).

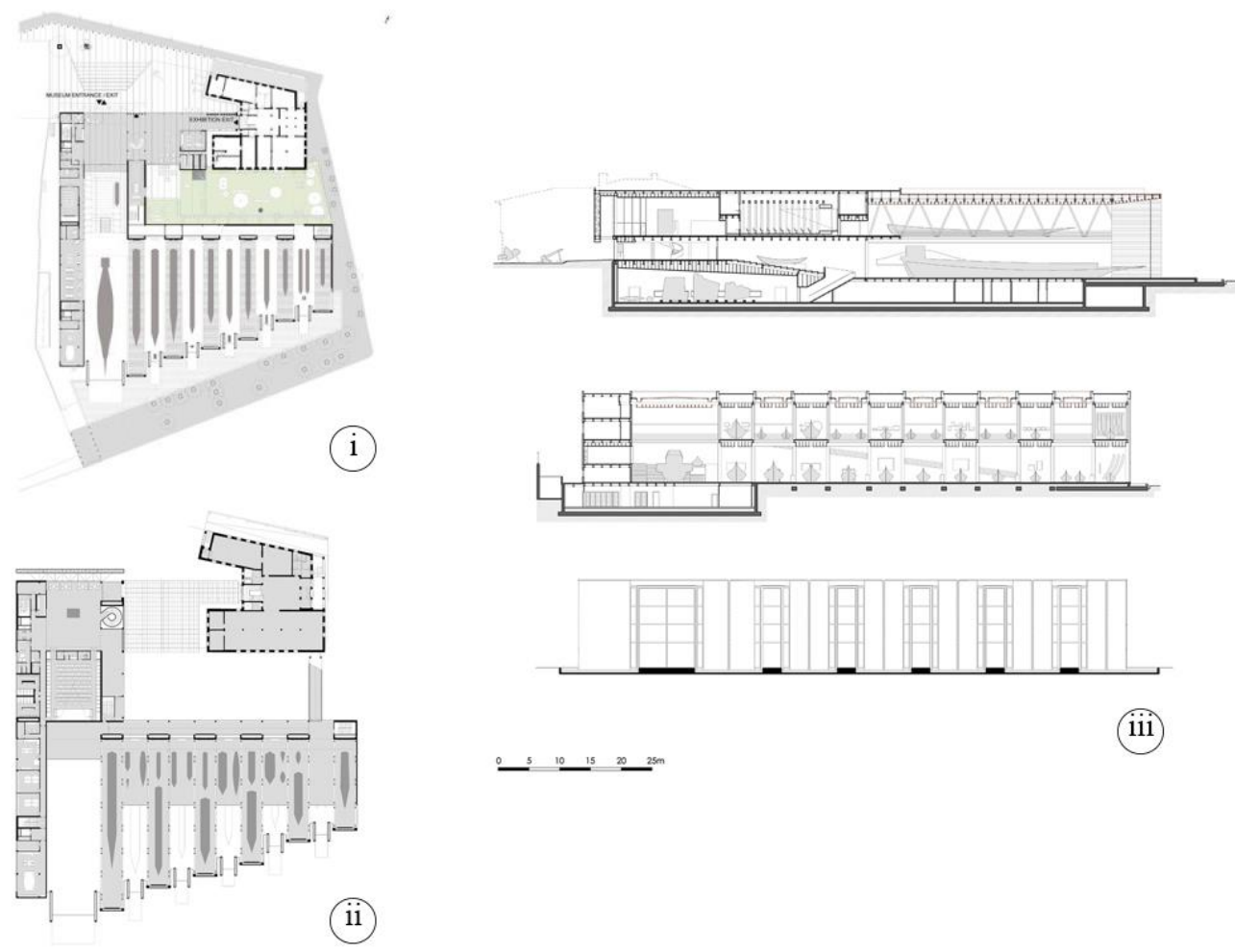

Şekil.1: i-Zemin Kat Planı, ii-Asma Kat Planı, iii-Kesitler (URL-2)

Deniz Müzesi resim, gemi donanımları, madalyalar, armalar, tuğralar gibi farklı türde birçok esere sahip olmasının yanı sıra, dünyanın en zengin tarihi kayıklar koleksiyonlarından birini bünyesinde barındırmaktadır. Sürekli sergi olarak kullanılan Tarihi Kayıklar Galerisi’nde kronolojik ve tematik bir düzen benimsenmiştir. Ayrıca sergilenen kayıklarla ilgili duvara asılan resim ve gravürler sayesinde, kayıkların kullanıldığı dönemler hakkında izlenimler edinilmesi sağlanmaktadır (Demir, 2019).

Sergilenen kayıklar ve kayık maketlerinin en iyi algılanmasını sağlayan ışık gün ışığıdır. Sergi salonlarına güneye bakan büyük camlardan ve tavanlardaki yarıklardan gün ışığı alınmaktadır. Günışı̆ııın sürekliliğini sağlamak amacıyla cephelerden tavana devam eden yarıklar oluşturulmuştur. Ancak iç kısımlara yeterli gün 1şı̆ı̆ gelmemesi ve mevsimsel olarak güneşin kontrol edilememesi nedeniyle, aydınlık seviyesi ayarlanabilir bir yapay aydınlatma sistemi mevcuttur. Bu sistem, bakır tavan içine gömülü yönlendirilebilir halojen lambalardan oluşmaktadır (Sapchi, 2016). 
Sirkülasyon alanları olan merdiven ve rampalar gün ışı̆̆ı ile aydınlatılmaktadır. Sergi salonlarını birbirine bağlayan, aynı zamanda sergilemenin devam ettiği rampa, yüksek pencereler ve cephelerdeki şerit pencerelerden ışık almaktadır. Ancak bu ışığın yetersiz kalması durumunda kullanılan, rampa boyunca devam eden bir floresan dizisi oluşturulmuştur. Floresanların şerit şeklindeki dizilimi sayesinde yönlendirme hissi uyandırılmıştır.
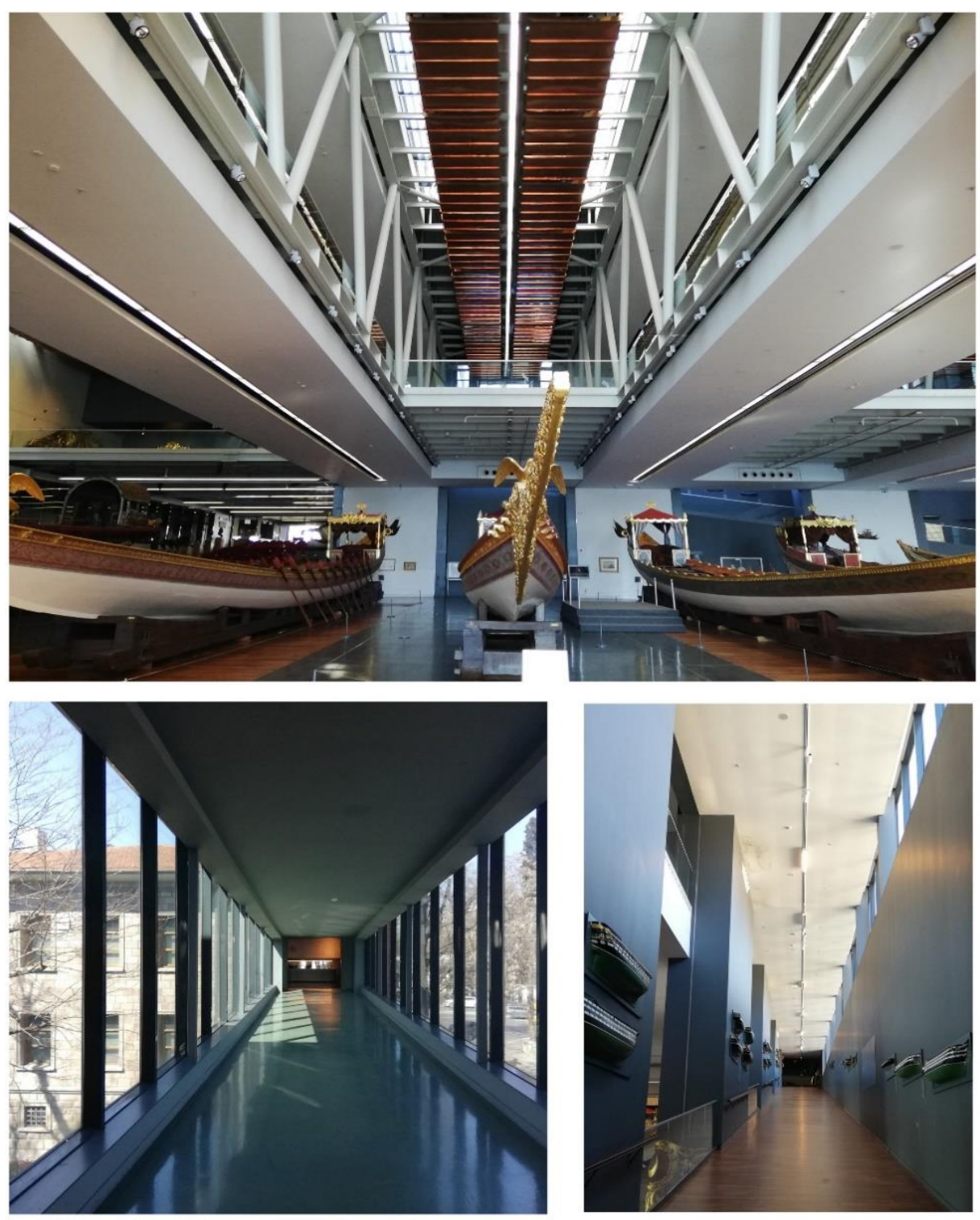

Resim.1: Kaylkhane Binast.

Müzede sergilenen kayıklar, bahriyeli üniformaları, maketler, sancaklar, haritalar, armalar ışığa duyarlı nesnelerdir. Sergilenen nesnelerin hepsi tarihi değer taşımaktadır. Müzenin en değerli parçası tarihi kadırga olarak görülmektedir. Işı̆̆a az duyarlı objeler sınıfındaki ahşap malzemelerden yapılmış ve üzerinde farklı boyalar kullanılarak yapılmış kabartma ve bezemeler bulunmaktadır. Sergilenen kayıkların zarar görmemesi için gereken maksimum aydınlık düzeyi 200 lx’tür (Sapchi, 2016). Ayrıca güneye bakan cepheden alınan gün ışı̆̆ı, cam kenarının ısınmasına ve nesnelerin ısıya bağlı bozulmasına neden olabilmektedir.

Sergi alanı rotasının parçası olarak müzeye dahil edilen tarihi binada, sergileme alanları içine gün ışı̆̆ı alınmamaktadır. Bu bölümde daha küçük objeler bulunduğundan, genellikle cam vitrinlerde sergileme yapılmaktadır. Vitrinlerin aydınlatılması, tavan yüzeyine yerleştirilen, yön değiştirebilir küçük spotlarla sağlanmıştır. Sergilenen objenin niteliği ve sergilendiği yöne göre bazı durumlarda tavana yerleştirilmiş spotlar veya led ışıklardan yararlanılmıştır. Müzenin bu bölümünde objelerin vurgulu aydınlatılması fikri hakimdir. Tarihi yapı içine gün ışığının alındığı tek mekân, sirkülasyonun sağlandığı merdivenlerdir. 

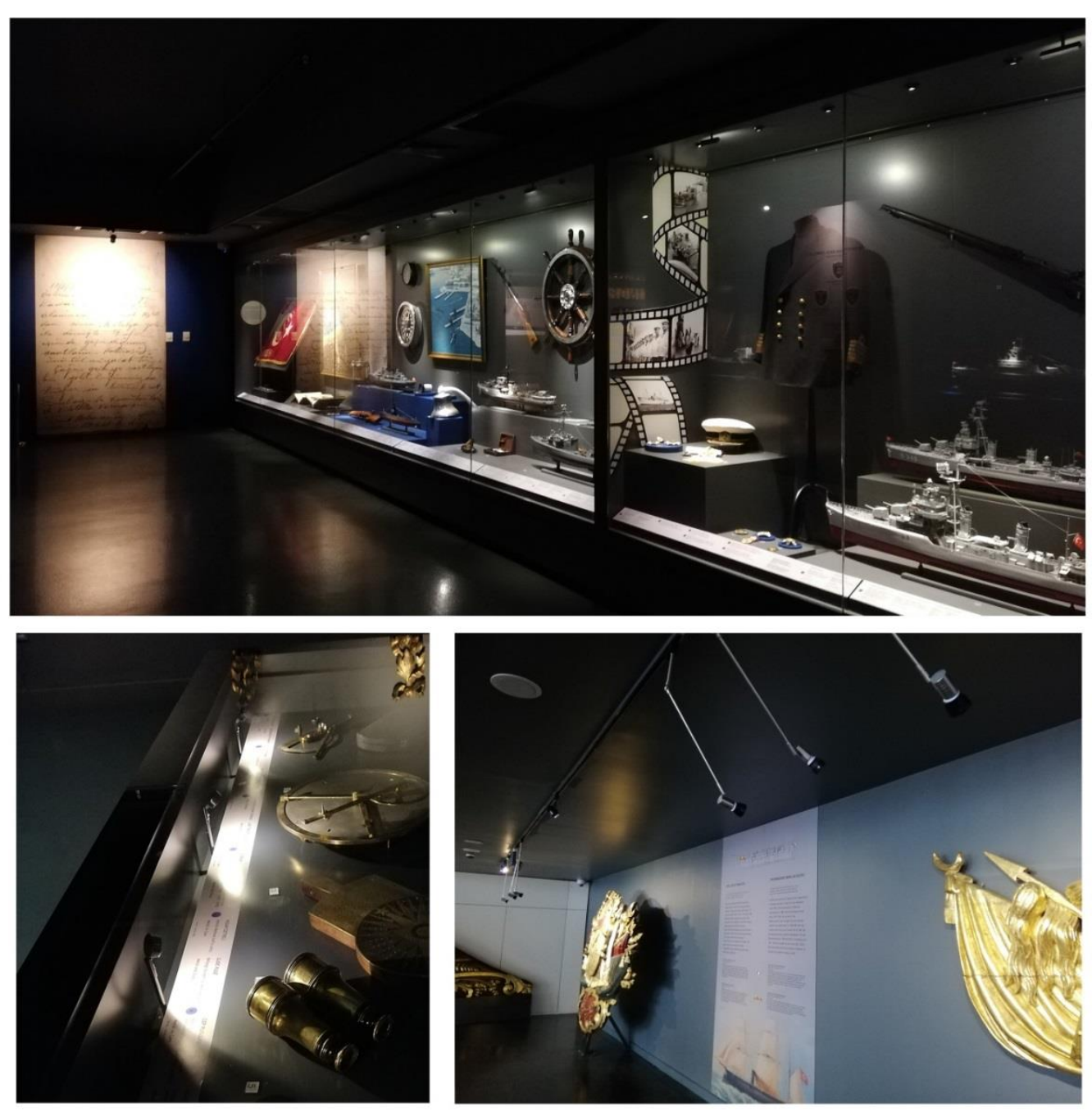

Resim.2: Deniz Müzesi Tarihi Binasında Aydınlatma Öğeleri.

\subsection{Sakıp Sabancı Müzesi, İstanbul}

Sabancı ailesinin içinde yaşadığı Atlı Köşk’ün müzeye dönüştürülmesi ile oluşmuştur. Başlangıçta Sabancı ailesinin hatıra ve koleksiyonlarının sergilendiği bir müze iken, 2002 yılında modern galeri ekiyle kapsamını genişletmiştir. Ailenin koleksiyonuyla birlikte, temalı süreli sergilere de ev sahipliği yapmaktadır (Uçar, 2008).

Müze koleksiyonu, 1940 yılında Hacı Ömer Sabancı tarafindan küçük heykeller, madeni eşyalar, porselen ve mobilyalarla oluşmaya başlamıştır. 1970’lerin ortalarından itibaren ise Sakıp Sabancı'nın müzayedelerden aldığı Türk resimleri, ardından Osmanlılara ait tombak ve gümüşler ile 500 yıllık geçmişe sahip hat koleksiyonu eserler arasına eklenmiştir (Öztekin, 2014).

Süreli sergilerde müze, ikili sanat anlayışı benimsemiştir. Tarihsel sergilerle koleksiyonlara uzak kalmamak, sanatsal sergilerle de toplumla ilişki kurmak hedeflenmektedir. Ayrıca geleneksel özelliklerini kaybetmeden gelişim gösterme çabası görülmektedir. Farklı konularda yapılan süreli sergiler, müzenin hep gündemde kalmasını ve sanat ortamı oluşturmasını sağlamaktadır. Yabancı koleksiyonlara da ev sahipliği yaptığından, yurtdışıyla da etkileşim halinde kalınmaktadır (Çelik, 2012).

Müze, Atlı Köşk ve modern galeri olarak iki bölümden oluşmaktadır. Atlı Köşk'ün üç odası Sabancı ailesinin bıraktığı haldedir. Kalan kısmı ise müze koleksiyonunun sergilenmesi için kullanılmaktadır. Süreli sergiler, köşke ek olarak yapılan modern galeride gerçekleştirilmektedir. Ayrıca müze kompleksi içinde bunlara ek olarak; kafe, müze mağazası, eğitim bölümü ve idari ofisler yer almaktadir. 

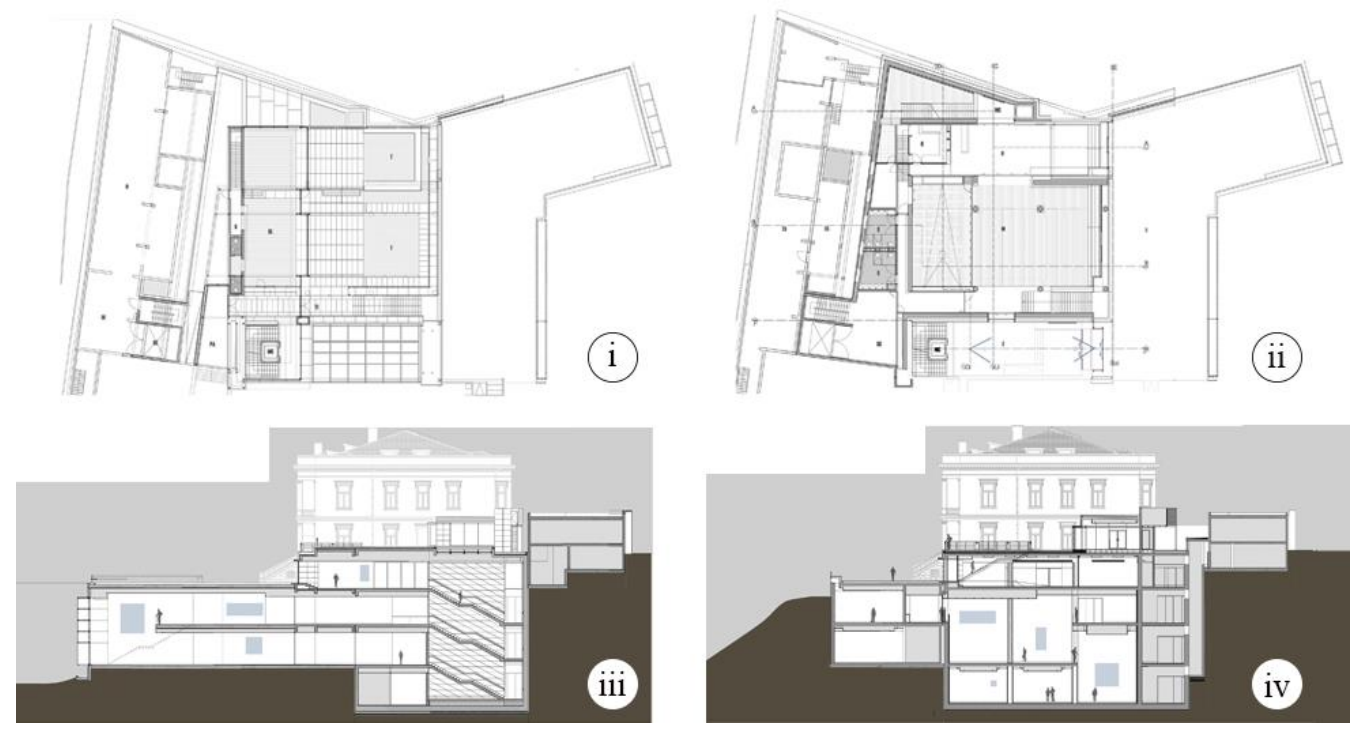

Şekil.2: i-Zemin Kat Planı, ii-1. Kat Planı, iii-Modern Galeri Kesiti, iv-Modern Galeri ve Atll Köşk Kesiti (URL-3)

Atlı Köşk’te Sabancı ailesine ait mobilyalar ve değerli eşyaların sergilendiği bölüm, ailenin bıraktığı şekildedir ve aydınlatma olarak avizeler kullanılmaktadır. Avizelerin çevresine yönlendirilebilir spotlar ilave edilmiştir. Bu bölümün koridorlarında müze koleksiyonuna ait tablolar sergilenmektedir ve objelerin vurgulu aydınlatılmasını da sağlamak amacıyla tavandaki ray sistemi içinde hareketli spotlar yer almaktadır.
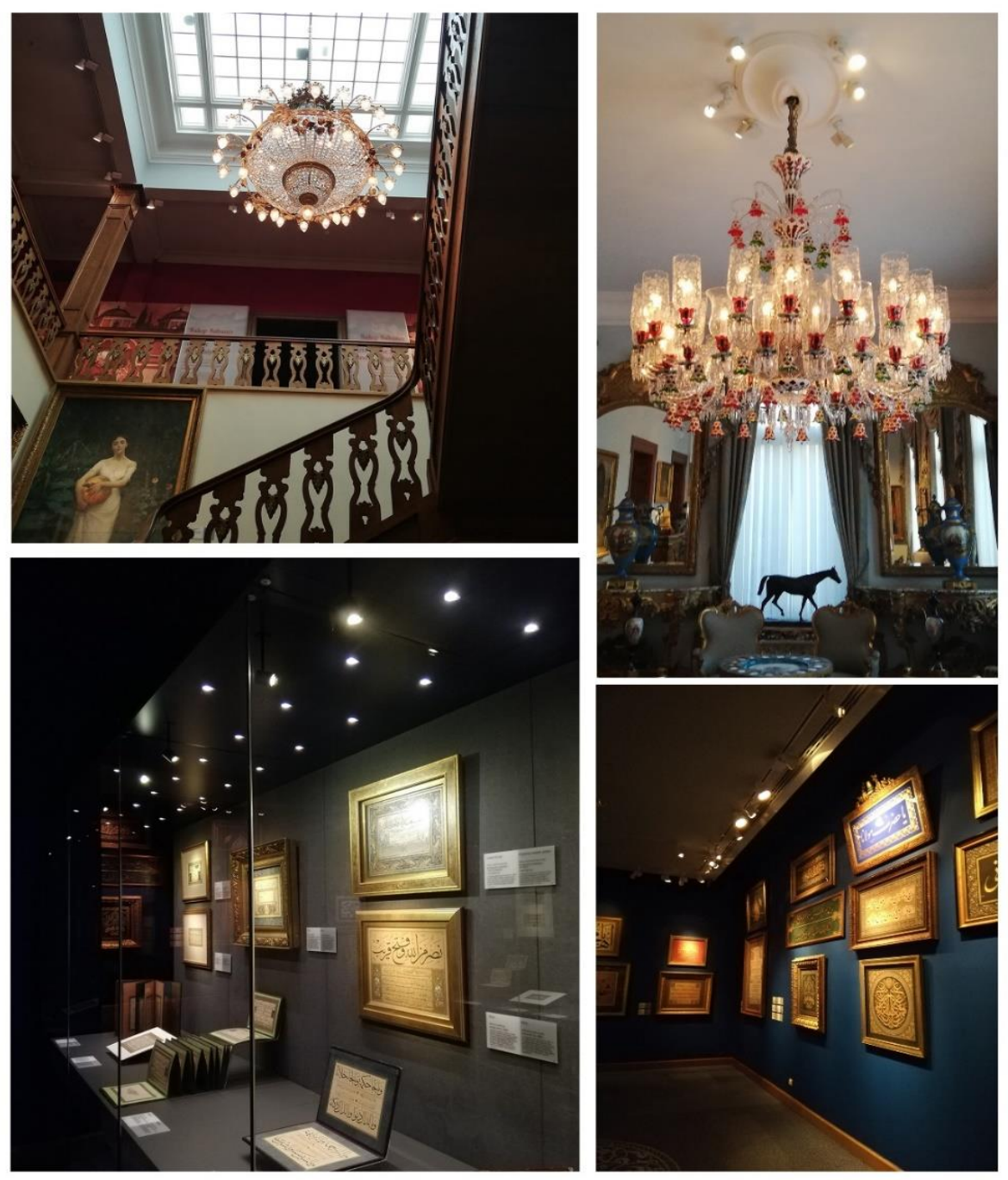

Resim.3: Atlı Köşk. 
Kitap ve hat koleksiyonunu sergilendiği salonlarda koyu renkler tercih edilmiş ve 1şık düzeyi minimum seviyede tutulmuştur. Eserler ahşap, metal ve camdan yapılmış vitrinlerde sergilenmektedir. Vitrinlerin tavan yüzeyine çok sayıda küçük spotlar yerleştirilmiş̧ir.

Işıktan yararlanmak ve şeffaflık hissi amacıyla modern galerinin ön cephesi cam olarak tasarlanmıştır (Öztekin, 2014). İç mekân aydınlatması ise tavandaki ray sistemi içindeki hareketli spotlarla sağlanmaktadır. Modern galeri içindeki yüksek tavanlı büyük salon, camlı tavan detayı ile aydınlatılmaktadır. Bu salona üst kottan camlarla bağlanan sergi alanı da tavan sisteminin ışığından faydalanmaktadır. Koridorlarda sirkülasyon aksı boyunca tavana şerit halinde floresanlar yerleştirilmiştir. Merdiven boşluğu aydınlatması ise cam tavan ve duvardaki floresanlarla sağlanmaktadır.
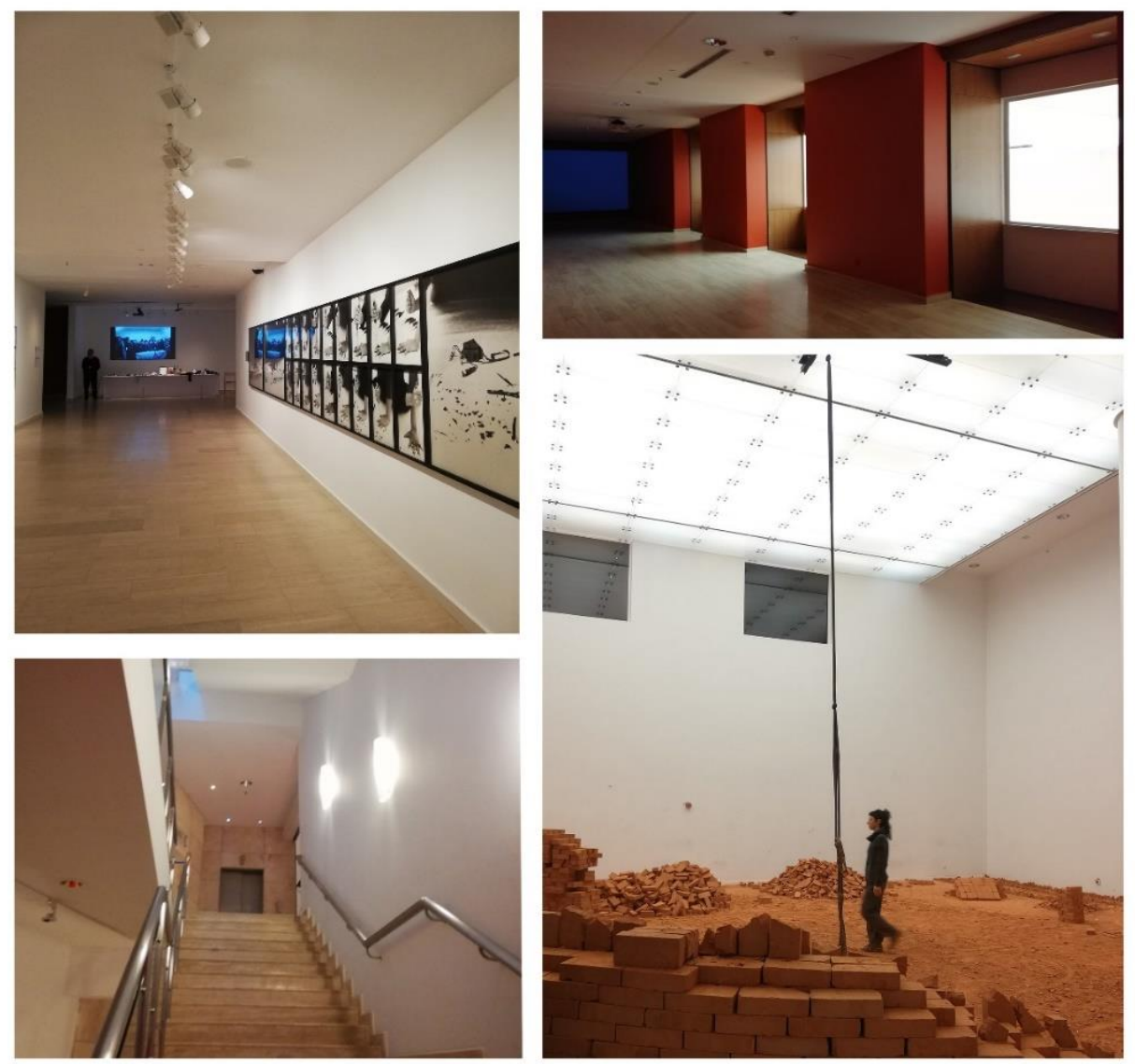

Resim.4: Sabancı Müzesi Modern Galerisi.

\section{Sonuç}

Müzeler 16. yüzyılda sergileme işleviyle ortaya çıkmışlardır. 19. yüzyılda işlevleri genişletilmiş, 20. yüzyılda koruma konusu da gündeme gelmiştir. Günümüz müzeleri, sadece sergi unsuru olarak kullanılmayıp içinde barındırdığı şehrin aktiviteleriyle birer odak noktası haline gelmiş ve sürekli aktif kullanılan yapılara dönüşmüşlerdir. İçerisinde birçok işlevi barındırsa da ana fonksiyonu sergilemedir. Sergi esnasında amaç nesnelerin olabildiğince doğru algılanması ve tanımlanmasıdır. Eserler, tarihi ve kültürel değer taşıdığından fiziksel temas, ortaya çıkabilecek hasarlar nedeniyle mümkün değildir. Bu sebeple aydınlatma sistemi görsel konforun sağlanması, objelerin ve mekanın algılanmasında etkilidir. Aydınlatma tasarımı, sergilenecek objeye ve sergi mekanına göre değişkenlik göstermektedir. Bazı durumlarda eserlerin tek tek algılanması ve ince ayrıntıların incelenmesi amaçlanırken bazı durumlarda sergi bir bütün olarak ele alınır. Hatta mekan da serginin bir parçası olarak kullanılabilmektedir. Aydınlatma sistemi eserlerle birlikte mekanı da hoş göstermeyi ve davetkar olmayı hedeflemelidir. Ayrıca oluşabilecek kazaları önlemek adına ziyaretçilerin yön ve mesafe bulmasını sağlayabilecek derecede aydınlık sağlanmalıdır.

Aydınlatma tasarımı, sergi elemanlarının algılanması kadar korunması konusunda da bir etkendir. Eserlerin tahribatı durumunda geri dönüşü çok zor olacağından, korunması da sergilenmesi kadar önem kazanmaktadır. Miktarı ve şiddeti doğru ayarlanmamış ışığın, nesneler üzerinde renk değişikliği, yapısal zayıflama ve kırılganlaşma, yüzeysel çatlak ve kırılmalar, ışık kaynağından yayılan 1Sı nedeniyle genleşme veya formunda değişiklikler gibi etkileri olmaktadır. Sergilenen materyallerin ışıktan etkilenmesini en aza indirmek için ışık miktarı belirlenen azami düzeyde olmalıdır ya da nesne direkt ışığa maruz bırakılmamalı, yansıtılmış ışıkla aydınlatılmalıdır. Güneş 1şı̆̆ kontrolü günün belli saatlerinde ve mevsimsel olarak farklılık gösterdiğinden kontrolü zordur. Bu nedenle yapay aydınlatmalar öncelikli olarak tercih edilmelidir. Bununla birlikte nesnelerin ışığa maruz kalma süresi azaltıldığında da 1şı̆̆a bağlı tahribatlar azalacaktır. 


\section{Kaynakça}

Akgün, B. (2018). Müze Sergileme Vitrinleri ve Mağaza Vitrinlerinin Aydınlatma Tekniği Kuralları Açısından Karşlaştırılması, Yüksek Lisans Tezi, Işık Üniversitesi Sosyal Bilimler Enstitüsü, Ankara.

Bayer, Y. (2007). Sergi Salonu Aydınlatmasında Genel İlkeler ve İki Sergi Salonunun İncelenmesi, Yüksek Lisans Tezi, Yıldız Teknik Üniversitesi Fen Bilimleri Enstitüsü, İstanbul.

Çelik, Ş. (2012). Türkiye'de Özel Müzecilik ve Baksı Müzesi,Yüksek Lisans Tezi, Atatürk Üniversitesi Sosyal Bilimler Enstitüsü.

Demir, B. (2019). Deniz Müzesi Koleksiyonunda Bulunan Saltanat Kayıklarının ve Sergileme Yaklaşımının Değerlendirilmesi, Yüksek Lisans Tezi, İstanbul Üniversitesi Sosyal Bilimler Enstitüsü.

Doğruer, F. S. (2019). Müzelerde Önleyici Koruma: Temel Yaklaşımlar ve Gelişimi. Akademik Sanat; Sanat, Tasarım, Bilim Dergisi, sayl: 22, s:122-134.

Erdemir, G. (2014). Müze ve Sergi Mekanlarında Aydınlatma Prensiplerinin Örnek Uygulamalar Üzerinden Değerlendirilmesi, Yüksek Lisans Tezi, İstanbul Teknik Üniversitesi, İstanbul.

Ganslandt, R., and Hofmann, H. (1992). Handbook of Lighting Design. Braunschweig: Vieweg-Verlag.

Giray, G. M. (2009). Sir John Soane Müzesi Mimari ve Aydınlatma Özellikleri, Yüksek Lisans Tezi, Ankara Üniversitesi.

Gordon, G. (2003). Interior Lighting for Designers (4. Bask1). John Wiley\&Sons Inc.

Hunt, E. G. (2009). Study of Museum Lighting and Design, Unpublished Master's Thesis, Texas State University, San Marcos, Texas.

Kasap, M. (2016). Mekansal Aydınlatmanın Bir Çağdaş Sanat Ürünü Olarak Ele Alınması ve Örneklenmesi, Doktora Tezi, Mimar Sinan Güzel Sanatlar Üniversitesi Fen Bilimleri Enstitüsü.

Kazanasmaz, T. (2003). Müzelerin Aydınlatma Tasarımı-ODTÜ Müzesi. II. Ulusal Aydınlatma Sempozyumu ve Sergisi Bildirileri.

Kurtay, C., Aybar, U., Başkaya, A., \& Aksulu, I. (2003). Müzelerde Algılama ve Aydınlatma Kriterlerinin Analizi: Ankara-Anadolu Medeniyetleri Müzesi Orta Holü. Gazi Üniv. Müh. Mim. Fak. Der., 18(2), 95-113.

Okan, B. (2018). Günümüz Müzecilik Anlayışındaki Yaklaşımlar ve Müze Oluşumunu Etkileyen Unsurlar. Tykhe Sanat ve Tasarım Dergisi, 03(04), 215-242.

Oğuz, G. P., \& Işık, N. (2003). Tarihi Yapılardaki Doğal ve Yapay Aydınlatma Uygulamaları. II. Ulusal Aydınlatma Sempozyumu Ve Sergisi Bildirileri, 1-5. Diyarbakır.

Öztekin, O. A. (2014). Müze Kavramı ve Müze Yapılarının İç Mekanlarının İstanbul'dan Örneklerle İncelenmesi, Yüksek Lisans Tezi, Haliç Üniversitesi Fen Bilimleri Enstitüsü.

Sapchi, A. T. (2016). Sürdürülebilir Müzelerde Mekânsal Tasarım Kriterleri ve Gün Işığı Kullanımı, Yüksek Lisans Tezi, Hacettepe Üniversitesi Güzel Sanatlar Enstitüsü.

Sirel, Ş. (2012). Aydınlatma Sözlüğü. Yapı Fiziği Uzmanlık Enstitüsü, İstanbul.

Soygeniş, S. ve M. (1992). ABD ve Kanada'dan Müze Binaları. Mimarlık Dergisi, 1(30), syf. 58-63.

Şener, F. (2009). Lighting In Museum Buildings And Investigation Of A Case Study, Yüksek Lisans Tezi, İstanbul Teknik Üniversitesi, İstanbul.

Şenyurt, H. (2009). Müze Mimarisinde Dikkat Edilmesi Gerekli Hususlar (Orta Ölçekli Taşra Müzeleri). URL:https://www.academia.edu/35739439/M\%C3\%9CZE_M\%C4\%B0MAR\%C4\%B0S\%C4\%B0NDE_D\%C4\%B0KKAT_ED $\% \mathrm{C} 4 \% \mathrm{~B} 0 \mathrm{LMES} \% \mathrm{C} 4 \% \mathrm{~B} 0$ GEREKL\%C4\%B0_HUSUSLAR_Orta_\%C3\%961\%C3\%A7ekli_Ta\%C5\%9Fra_M\%C3\%BCzeleri_ (E.T: 05.11.2019)

Uçar, N. (2008). İstanbul'da Sanatsal Alanın Yeni İkonları, Yüksek Lisans Tezi, İstanbul Bilgi Üniversitesi Sosyal Bilimler Enstitüsü.

Yarımay, Ö. (2018). İstanbul'da Müze Olarak Tasarlanan Yapıların Mimari Kimlik Bağlamında İrdelenmesi, Yüksek Lisans Tezi, Yıldız Teknik Üniversitesi Fen Bilimleri Enstitüsü.

Yöndem, İ. A., \& Akyol, A. A. (2017). Müzelerde Aydınlatma Kriterlerinin Sergideki Malzemelerin Korunmasına Etkisi: Çengelhan Rahmi Koç Müzesi. Sosyal Bilimler Dergisi, sayı 12, syf. 526-542.

Yöndem, İ. A. (2019). Ankara’daki Müze Örneklerinde Aydınlatma Yöntemleri ve Önleyici Koruma Yöntemi Olarak Işı̆̆ı̆n Denetimi, Doktora Tezi, Gazi Üniversitesi.

URL-1: http://www.fotonelektroteknik.com.tr/aydinlatma-terimleri/ (E.T:06.03.2020)

URL-2: https://www.arkitektuel.com/istanbul-deniz-muzesi/ (E.T:11.03.2020)

URL-3: http://www.vitracagdasmimarlikdizisi.com/projeler/Sak\%C4\%B1p-Sabanc\%C4\%B1-Muzesi.aspx (E.T:12.03.2020) 